\title{
Marburg hemorrhagic fever
}

INSERM

\section{Source}

INSERM. (1999). Orphanet: an online rare disease and orphan drug data base. Marburg hemorrhagic fever. ORPHA:99826

Marburg hemorrhagic fever (MHF), caused by Marburg virus, is a severe viral hemorrhagic disease characterized by initial fever and malaise followed by gastrointestinal symptoms, bleeding, shock, and multi-org an system failure. 